

\section{EXEMPLI GRATIA}

SAGALASSOS,

MARC WAELKENS AND

INTERDISCIPLINARY

ARCHAEOLOGY

Edited by Jeroen Poblome 
(C) 2013 by Leuven University Press / Presses Universitaires de Louvain / Universitaire Pers Leuven. Minderbroedersstraat 4, B-3000 Leuven (Belgium).

All rights reserved. Except in those cases expressly determined by law, no part of this publication may be multiplied, saved in an automated datafile or made public in any way whatsoever without the express prior written consent of the publishers.

ISBN 9789058679796

$\mathrm{D} / 2013$ / 1869 / 59

NUR: 682

Lay-out and cover design: Frederik Danko (Vuurvlieg)

Jacket photographs: Statue of Hadrian $\odot$ Bruno Vandermeulen (KU Leuven)

and Marc Waelkens $\odot$ Yves Nevens (Belspo) 


\title{
Money Makes Pottery Go Round
}

\author{
Jeroen Poblome
}

I do not drink a lot of alcohol. A cool Efes at the end of a campaign working day or a bottle of Côte de Beaune in the company of friends go a long way. The most savoured moments are enlightened by a top-range single malt whisky, however, and there is a good reason for that. Until I was 30 the most important decisions in life were taken over a glass or two (or more) in the company of my late father, Noel Poblome. Things were no different one spring evening in 1991. While doing my Belgian army service upon graduating from university, Professor Marc Waelkens had approached me to initiate a Ph.D. in archaeology on what were then called the fine wares of Sagalassos, funded by the initial Interuniversity Poles of Attraction Programme newly granted to him. As I had in the meantime submitted a Ph.D. proposal to the Belgian National Fund for Scientific Research on the Roman cemeteries in NW Gaul, promoted by Professor André Van Doorselaer, there seemed to be reason enough to drink some glasses of whisky to ponder options. Of course, I was attracted by the exotic aspects of starting to work in Turkey, but truth be told I knew nothing of the country, as our family holidays were never spent in countries east of France or Spain. Obviously, my father thought that starting a Ph.D. in archaeology was already a sufficient adventure in itself, no matter in which country. Twenty-three campaigns in Sagalassos later, the detail of our father-son discussion now escapes me but our late night conclusion should be clear enough.

There is a lot I owe to Marc, but he knows me well enough to understand that I prefer to express deep gratitude in simple terms. Indeed, the fact that I never regretted joining his Sagalassos Archaeological Research Project for a single second since spring 1991 is what I owe him most. The added value his archaeological brain-child continues to represent in my life, as in the lives of everybody who has ever participated in the Sagalassos campaigns, is incomparably more important than any academic freedom and support he has granted me.

Therefore it is my honour to present him this contribution on the very topic he offered me in 1991: Sagalassos red slip ware (or SRSW), combining beloved aspects of interdisciplinary archaeology, albeit mostly within the humanities, with a bit of beloved Sagalassos. My research question is simple: ever since the discovery of the so-called Potters' Quarter of Sagalassos in $1987^{1}$, it has seemed obvious to Marc and his Sagalassos Project that the produce of the local potters helped to oil the wheels of Sagalassos' economy. But are there ways to validate this implicit assumption, or at least circumscribe better how this would

1 Mitchell and Waelkens 1988, p. 60. 


\section{Jeroen Poblome}

have worked in economic terms? As I recently revisited the production organisation of the Sagalassos potters ${ }^{2}$, this contribution will deal with three related issues: can pottery consumption rates be described, can the economic value of pottery be established, and how did artisanal production form part of the structure of the ancient economy?

\section{What pottery to expect?}

Finding sherds of pottery is inevitable no matter which excavation or survey project at any site or region within the extensive Roman Empire. Considering the durability of pottery as a material category and the way that other material categories, such as glass or metals, were recycled in antiquity or only survive in exceptional circumstances in the archaeological record, such as wood, leather or other organic matter, the quantities of registered sherds actually represent a distorted truth as to how pottery functioned proportionally compared to other objects in frequent use in past daily practices. Notwithstanding this important observation, the total quantity of pottery consumed within the Roman Empire must have been humongous.

J. Theodore Peña ${ }^{3}$ introduced the concept of life-cycle into the field of Roman pottery studies, in order to elucidate behavioural practices related to pottery manufacture, distribution, prime use, re-use, maintenance, recycling, discard and reclamation, and how these past practices contributed to determine which pottery eventually ended up in the archaeological record and how. In this context, his estimations of vessel use-life are of importance, as defined for dolia, amphorae, oil lamps, cooking wares, utilitarian wares and tableware. Ted Peña acknowledges that his observations are '... only very general and, in many cases, somewhat speculative comments regarding the probable use-lives of the six functional categories of Roman pottery, basing these on logical considerations of the several factors likely to have affected use-life and a limited amount of direct evidence ${ }^{4}$. Even though every single Roman pottery specialist no doubt has one or more remarks on the particularities of the estimations of use-life or the methodological choices, I consider the research questions and general framework introduced by Ted Peña as a useful contribution to pulling Roman pottery studies out of their traditional typo-chronological framework. There is nothing wrong with classification, typology and chronology, but I, as Ted Peña, consider it as part of my academic brief to continue to play the devil's advocate in line with recent initiatives ${ }^{5}$, in order to enliven the debate of Roman pottery studies and mainly to increase its value for the study of the Roman world in general.

For dolia a prime use-life of 20-30 years or longer was suggested and a mean use-life of 25 years $^{6}$, for amphorae 20 years or longer as use-life and 5 years as mean use-life ${ }^{7}$, for oil lamps in general less than 1 year and a mean use-life of 0.5 year $^{8}$, for cooking wares

\footnotetext{
2 Poblome, in press.

3 Peña 2007.

4 Peña 2007, p. 42.

5 Poblome et al. 2007; 2012b.

6 Peña 2007, p. 46-47; 325-326.

7 Peña 2007, p. 47-56; 325-327.

8 Peña 2007, p. 56-57; 327-328; 330.
} 
the same short time-span as with oil lamps and a mean use-life of 0.5 year $^{9}$, for utilitarian wares more variable amounts of time were suggested and a mean use-life of 3 years ${ }^{10}$ and for tableware no more than 1 year with a mean use-life of 3 years ${ }^{11}$.

To be sure, pottery was used by people. This paper does not have the intention to enter into the detail of the debate on demography in Roman Imperial times. Instead, I lean on Walter Scheidel's recent contribution on the matter ${ }^{12}$. By mid-second century AD, the size of the population of the Roman Empire is estimated at between 60 to 70 million, with $20 \%$ of the total residing in the Asian provinces. Considering that, in general, production of tableware is an urban function, the level of urbanization is also important to consider. The total number of cities in the Roman Empire probably approached 2,000 and the aggregate urban population between 7 to 9 million. Typically, apart from a few major cities, most urban communities were small, including fewer than 5,000 residents. Sagalassos was part of this league of small towns, in a traditionally urbanized region of the empire.

The bulk of the population of these urban communities would have formed part of households. These are essential building blocks in the reconstruction of past societies, in representing measurable socio-economic units and functioning as basic units of production and consumption, also of pottery. Once again I cannot enter into details in this context. M.H. Hansen ${ }^{13}$ estimated the average urban household in antiquity to contain five to seven members. Considering mortality rates, household fragmentation and reconstitution must have been typical processes. Notwithstanding these dynamics, a household generation is considered to have lasted about 30 years, and an average urban community to have contained between 300-700 households.

From the combination of pottery use-life estimates with demographic ones, it seems to become possible to assume some theoretical pottery consumption rates for an average, urban, Roman Imperial household:

- Medium to large storage vessels: 1 for each household and a second one in every other household: $450-1050$ vessels/30 years

- Amphorae: each year 1 wine and 1 olive oil amphora for each household: $600-1,400$ vessels $/$ year $=18,000-42,000$ vessels $/ 30$ years

- Oil lamps: 5-10 in each household: 3,000-14,000 lamps/year = 90,000-420,000 lamps/30 years

- Cooking wares: 1 casserole, 1-2 frying pans, 3-6 cooking pots: 10-18 vessels/year/ household; 3,000-12,600 vessels/year $=90,000-378,000$ vessels $/ 30$ years

- Utilitarian wares: 1 mortarium, 3-5 lekaneis, 3-5 jugs: 7-11 vessels/3 years/household; $2,100-7,700$ vessels $/ 3$ years $=21,000-77,000$ vessels $/ 30$ years

- Tableware: 3-5 cups, 0-2 plates/trays, 5-7 bowls, 7-10 dishes: $15-24$ vessels/3 years $/$ household; 4,500-16,800 vessels $/ 3$ years $=45,000-168,000$ vessels $/ 30$ years

\footnotetext{
9 Peña 2007, p. 57-58; 327-328; 330.

10 Peña 2007, p. $58 ; 328-329 ; 331$.

11 Peña 2007, p. 58-60; 329-330; 331.

12 Scheidel 2007.

13 Hansen 2006.
} 


\section{Jeroen Poblome}

Table 1 expresses these approximations in order of magnitude in consumption. It needs to be stressed these are entirely personal assumptions, expressed as a working hypothesis, based on an appreciation of Roman society as technologically complex with a fair degree of specialization in object fabrication and usage, and most Roman Imperial households hanging between poor and rich, allowing basic, yet differentiated and functionally specific consumption patterns of material culture. Some of the same insights were also applied in an earlier study on the estimation of sigillata and red slip ware tableware production in the Roman East ${ }^{14}$.

\begin{tabular}{llll} 
& Minimum & Maximum & $\%$ \\
\hline Oil lamps & 90,000 & 420,000 & $34-38 \%$ \\
\hline Cooking wares & 90,000 & 378,000 & $34-35 \%$ \\
\hline Tableware & 45,000 & 168,000 & $17-15 \%$ \\
\hline Utilitarian wares & 21,000 & 77,000 & $8-7 \%$ \\
\hline Amphorae & 18,000 & 42,000 & $7-4 \%$ \\
\hline Dolia & 450 & 1050 & $0.1-0.01 \%$
\end{tabular}

Table 1. Estimated pottery consumption rates for 300-700 urban households/30 years, in the Roman Empire.

The proof of the pudding is in the eating, however. In this respect, the proportions of Table 1 are, for instance, difficult to compare to the end of sixth/seventh century AD household(?) dump located in Room 2 of the so-called North-East Building, located at its namesake's corner of the Upper Agora at Sagalassos. Here, an original, early Roman Imperial monumental structure, possibly incorporating a fountain, underwent many modifications during the course of its use. By the late fifth/sixth century AD, the interior space was subdivided by an arcade running through the length of the building, supporting vaulted spaces in the back part of the building. By the time of the household(?) material culture assemblage, both the spaces behind and in front of the arcade were divided into smaller rooms forming part of a larger, not completely excavated, multi-room unit, which was tentatively proposed to represent the remains of an early Byzantine house ${ }^{15}$. When considering Rim-Base-Handle counts of the pottery included in the household(?) dump in Room 2, SRSW dishes and bowls for food consumption account for $52.8 \%$ of the assemblage, followed by cooking vessels and lids in the local/regional fabric 4 for $20.1 \%$, jugs of various types for $14 \%$ (6.3\% in SRSW fabric, $7.1 \%$ in fabric 4 and $0.6 \%$ imported jugs), lekaneis/containers/basins mostly in SRSW fabric for $5.2 \%$, oil lamps in SRSW fabric for $2.5 \%$, local dolia for $2.4 \%$, local/regional fabric 4 amphorae for the same percentage and cups in SRSW fabric for $1.4 \%$. These are clearly different proportions when compared to the 'logical' assumptions of Table 1.

\footnotetext{
14 Willet and Poblome 2011.

15 Poblome et al. 2010.
} 
The picture becomes more complex when we compare these data with quantified functional proportions of material collected at the surface by the Leiden University 'Ancient Boeotia Cities Survey Project directed by John Bintliff, where I happily function as ceramic advisor for the late Hellenistic to early Byzantine periods. Fig. 1 presents totals of pottery for these periods from survey grids within the ancient towns of Koroneia and Tanagra that were considered from geophysical analysis and/or topographical, architectural and find assemblage observations to represent domestic zones. Not only are the attested proportions different between both Boeotian towns ${ }^{16}$, these are also not in line with the already mentioned totals.

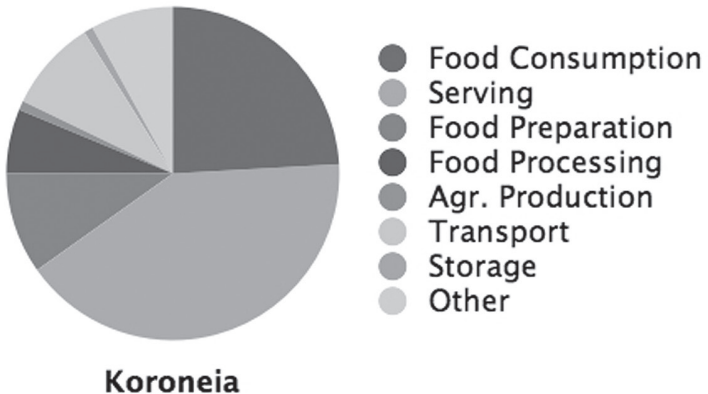

Grids 98B, 100A \& 101A LH-LR pottery $(n=112)$

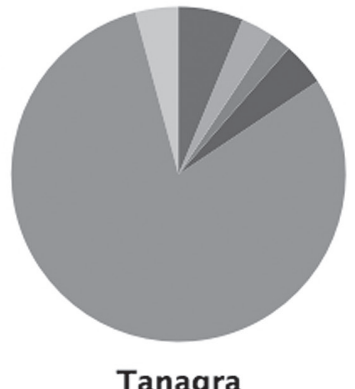

Grids $8 \& 12$ LR pottery $(n=96)$

Fig. 1. Surface pottery from supposed domestic zones.

Finally, when compared to a contemporary (partial) inventory of household objects found in the kitchen of the Praetorium at Vindolanda (Tabula Vindolandensis 194, dated to $97-102 / 3 \mathrm{AD}$ ) yet another picture emerges. The kitchen attendants could dispose of 2 scutulas or shallow dishes, 5 paropsides or side dishes, 3 acetabula or vinegar bowls, 3 ouaria or egg cups, a lancem or platter, another scutulam or shallow dish, one lucernam aeneam or bronze lamp, 2 calices or drinking cups and some Trullas [] theca or bowls in a box. Apart from the other material category that is represented, the functional variation in mainly tableware forms is interesting to note, apart from the absence of other functional categories from this admittedly partially preserved list.

So, although I am in favour of the recent trend towards accumulating 'soft statistics' on various aspects of antiquity, the logical, hypothetical assumptions put forward in order to circumscribe what amounts of pottery to expect in average Roman Imperial households cannot be confirmed based on 'real' datasets. Based on the nature and quality of the data available, generic modelling of Roman urban household 'patterns of pottery expectancy' is not (yet) possible. This does not mean, however, that we should stop collecting data, whilst, logically, patterns are expected to be different in function of time/space specific options of

16 See also Poblome et al. 2012a. 


\section{Jeroen Poblome}

supply and demand of pottery. Realising how difficult it still is to answer even fairly basic questions concerning aspects of daily life from a period that is generally considered to have been well-studied, provokes inspiration to focus our archaeological attention in different ways. For the time being, we are constricted to the semi-intellectual appreciation that the total quantity of pottery consumed within the Roman Empire must have been ... well ... humongous. The only way to somehow put a number on that is by looking back into the registries I used for my Ph.D. on the typology and chronology of Sagalassos red slip ware ${ }^{17}$. In those days, I used to process between 20 to 30 wooden crates of Sagalassos tableware per day, each containing between 500 to $800 \mathrm{Rim} /$ Base/Handle/Body-sherds of the local tableware, with working weeks of 5.5 days during campaigns of eight or so weeks. These practices are ongoing, but I especially should like to acknowledge the way Philip Bes and Nalan Frrat have stepped in to take over this task. This results in a minimum amount of processed Sagalassos red slip ware sherds of 440,000 and a maximum of 1,056,000 sherds per campaign. Over 23 years of fieldwork this rate of artefact processing implies that the Sagalassos project has classified, counted and weighed anything between 10,120,000 to $24,288,000$ sherds of Sagalassos red slip ware. And that's only tableware.

\section{What was the economic value of pottery?}

The fact that Sagalassos was a production centre of tableware (as a matter of fact, most other wares found on site were also made in the immediate vicinity) surely helps to boost such totals. But when considering the economic value of the enterprise, Sagalassos surely pales into insignificance when compared to the production centre(s) of Eastern Sigillata $A^{18}$, for instance, even though those have not been located yet. As this consideration of the economic importance of SRSW to Eastern Sigillata A is based on an implicit appreciation of the literature on the relevant exchange patterns, it is perhaps better, however, as a next step, to try and circumscribe the issue at hand from approaching the value and pricing of pottery vessels. Generally, ancient pottery is considered to have been fairly cheap and good quality sigillata tableware perhaps a little less so ${ }^{19}$. In what follows I provide some snapshots of pottery prices.

For instance, the 154 wax tablet business receipts of L. Caecilius Iucundus, which were discovered at Pompeii, list a pottery caliculum or small bowl bought for 2 asses and a pultarius or vase and patella or dish for 1 as each. These prices can be compared to a silver trulla or scoop valued at 90 denarii, equalling to 1,440 patellae ${ }^{20}$. Tabula Vindolandensis 588 (97-102/3 AD) reveals that that a set of cooking vessels was "ordered and brought through Adiutor from London" at a price of more than 10 denarii and that this price was considered to be relatively costly. Tabula Vindolandensis 596 dating to the same period lists "trullas, number 4, 5 denarii 1 as each - trullas, number 4, 3 and 7/8 denarii and 1 as each - trullas, number 4, 2 and 5/8 denarii and 1 as each", whereas P.Ox.36.4B.99/J(6), P.Ox.L3596 and P.Ox.L3597, all datable to the mid-third century AD, mention 32-36

\footnotetext{
17 Published as Poblome 1999.

18 Lund 2005.

19 Peña 2007, p. 27-31.

20 Andreau 1974.
} 
drachmas for 100 newly produced amphorae, equal to about 110-120 asses for 100 amphorae or 1.1-1.2 as for one new amphora. The Edictum Diocletiani de pretiis of $301 \mathrm{AD}$ provides a unique price overview for different functional categories of pottery: a dolium with a capacity of 1000 Italian sextarii (547 1) was priced at 1,000 denarii and was expensive, a vessel with a capacity of 2 Italian sextarii $(1.11)$ was very cheap at only 2 denarii, a lot of 10 ceramic lamps cost 4 denarii and a lagona with a capacity of 24 Italian sextarii was listed at 12 denarii, whereas amphorae were priced according to capacity, amounting to between $0.5-6.25 \%$ of the value of the content. The Diocletian prices for pottery vessels can be compared to listed values for vessels in other material categories, such as glass, with Alexandrian (colourless) glass cups and smooth vessels priced at 30 denarii to the pound and Judaean (blue-green) glass cups and smooth vessels at 20 denarii to the pound. With an average glass vessel weighing about 100-150 gm, two or three vessels could be made from a Roman pound of glass, equalling to 7 to 15 denarii per glass vessel, which is clearly more expensive than their ceramic counterparts. Glass bottles with a capacity of two sextarii weigh about 1-2 Roman pounds, making these glass items at least 10 times more expensive compared to pottery bottles. Finally, the papyrus archive of Theophanes, datable to around $320 \mathrm{AD}$, preserves a wealth of detail about the nobleman travelling from his native Hermopolis to Syrian Antioch and back. In general, it is interesting to note that the price inflation rate can be set at about five times the rates set out in the Price Edict of Diocletian, only a couple of decades earlier. Amongst the many purchases made during the journey and stay at Antioch, Theophanes and his company bought wooden bowls for 400 drachmas, a plate and a jar for 300 drachmas, equalling to 75 denarii or 6 nummi for each vessel, a Selinus wine jar at Tyre for 1,600 drachmas, or 400 denarii or 32 nummi, and he had his crockery repaired at Antioch for 100-200 drachmas or 25-50 denarii or 2-4 nummi. These prices can be compared to the total expenditure for the one month's stay of Theophanes at Antioch amounting to 112,400 drachmas or 5 aurei $^{21}$.

When this range of pottery prices is projected against typical wage levels of the period, it becomes clear that, in general, this was a standard, affordable commodity, especially as vessels did not have to be bought every other day. Within the senatorial census of 1 million sestertii and the eques census of 400,000 sestertii, these members of elite could afford as much pottery as they could dream of, as it were. But also considering the lower ranking wages of legionaries at 1,200 - 2,000 sestertii/year or 300-500 denarii/year, and documented wages of adult free males at $500-1,000$ sestertii/year or 125-250 denarii/ year, it becomes clear that wages were generally above minimum subsistence for an adult male, and even for a family, particularly if the wife and grown children also contributed to the household income ${ }^{22}$. The Edict of Diocletian also pronounces the value of unskilled labour at 25 denarii/day, plus a meal, and that of skilled labour at 50-60 denarii/day, plus a meal, which gives a good indication that pottery vessels were affordable next to a range of other goods, no doubt first catering for subsistence.

The attested levels of taxation will also not have prevented the inhabitants of the Roman Empire from purchasing daily commodities, such as pottery. The adjustable

21 Matthews 2006.

22 Jongman 2007. 


\section{Jeroen Poblome}

Imperial system of taxation is generally considered to have been beneficial and seems to have amounted to no more than $1 \%$ of the capital value of the land and certainly no more than $10 \%$ of annual revenue ${ }^{23}$.

From this concise overview it has become clear that pottery had a price in antiquity, but that it was generally affordable as well as available. In other words, considering the presumed amounts required for consumption, it should be clear that there was money to be earned in the artisanal production sector, and that this was not only restricted to sigillata or red slip ware tableware production. On the other hand, we should avoid recreating the economic value of pottery production from a naive understanding of the independent role of the market, based on distribution patterns and the (un)conscious application of Neoclassical economic theory. The impact of the craft sector should be measured in function of total production output, which, unfortunately but importantly, is difficult to calculate and not comparable to the representation of the different artisanal material categories in the archaeological record. Moreover, the impact of the craft sector will have been variable and a function of regional demographic patterns and space/time specific patterns of supply and demand.

\section{Finding a place in the ancient economy ${ }^{24}$}

The way in which individual potters or a collection of craftsmen linked to a workshop would have made a living was dependent on contemporary modes of production organisation. In a recent contribution on the production organisation involving the potters of SRSW ${ }^{25}$, I argued for less dependency on direct involvement/investment by upper classes in raw material management and production infrastructure, but rather a crucial role for the elite in creating favourable conditions in the urban economy allowing artisanal production to nestle. Instead, tenancy arrangements focussed on small-scale workshops functioning within the familia as typical operational matrix could have represented the hallmarks of artisanal production and ways of making a living in Roman antiquity. Successful types of tableware did not generate economies of scale or manufactories; rather the basic and economically independent production unit of the workshop was multiplied. When opportunity arose, loosely integrated networks of artisans and workshops were created based on subcontracting arrangements, possibly formulated in terms of locatio-conductio ${ }^{26}$. Third parties, such as members of the social elite, could also issue contracts in these terms, possibly in conjunction with providing access for tenants to raw materials and workshop infrastructure. In case sufficient critical mass in craft production was reached, collegia could be founded. These voluntary associations of professionals traditionally offered opportunities for sociability and conviviality, communal religious celebrations, a degree of social competition and visibility in the local community, as well as a trusted network of members to go about their business ${ }^{27}$.

\footnotetext{
23 Lo Cascio 2007.

24 This part drew inspiration from Berlage and Decoster 2005; Temin 2013; Persson 2010.

25 Poblome, in press.

26 Drexhage et al. 2002, pp. 107-112; Wieling 2000.

27 van Nijf 1997; Zimmermann 2002.
} 
The archaeology of Sagalassos proves sufficiently how this model can be successful at the regional scale. The question remains, however, how to define in economic terms the artisanal contribution to the ancient economy?

Basically, the discipline of economics studies how humanity evolved from answering to primary subsistence needs, to creating better welfare conditions. Achieving this aim is always dependent on limited means. Therefore, choices have to be made. The general capacity to cater for needs can be measured by determining the GDP of an economy, or its yearly rate of production of goods and services. GDP can also be used as an indicator to determine growth patterns, of which Marc and his Sagalassos project believe the production of SRSW to be a prime regional example. The downside of choosing which needs to satisfy and how, is that the employed means can no longer be used for other purposes or needs. The value of the best possible other - but not chosen - employment of those means is defined as opportunity costs. Opportunity costs are an abstract concept, translating the shortage of means and the restrictions binding each economic agent. Each economy, including that of ancient Sagalassos, is confronted with shortage of means, the need to make choices and the opportunity costs resulting from those choices. In this respect, the sky is not the limit. The curve on Fig. 2 represents the limits of possible production output of a given economy, say the one of Roman Imperial Sagalassos. In the case that all production means (land, labour, capital) are geared towards the production of subsistence goods, agricultural production capacity and output will reach its maximum (on the $\mathrm{Y}$-axis). In the case that all production means are geared towards artisanal production, material culture output will reach its maximum (on the $\mathrm{X}$-axis). Any other combination of production output, involving other types of goods as well, is of course also possible and depends on choices in economic behaviour. It is important to consider that the curve declines between the $\mathrm{Y}$ and $\mathrm{X}$-axis. This implies that every other piece of pottery made in Sagalassos represents an opportunity cost and therefore less output of subsistence goods. If artisanal production is small-scale (0-A on the $\mathrm{X}$-axis), say geared towards the needs of the own polis and hinterland, as was the case with the Hellenistic potters' quarter of Sagalassos ${ }^{28}$, the opportunity cost for subsistence goods is limited (A on the Y-axis). In an ancient economic context, heavily geared towards and dependent on agriculture in its widest sense, the limited production costs represented by small-scale artisanal production actually creates opportunities for diversification in economic activity, as is widely attested by the plethora of local/regional lines of pottery production throughout the Roman Empire. The reason why initial opportunity costs are limited follows from the fact that first the production means that are not optimally geared towards the production of subsistence goods are shifted towards the artisanate, keeping subsistence production output high. If, however, artisanal production output proportionally increases (between $\mathrm{B}$ and $\mathrm{C}$ on the $\mathrm{X}$-axis), say with the initiation of mass production of Sagalassos red slip ware in early Roman Imperial times, the opportunity costs will disproportionally rise with a greater loss of output of subsistence goods as a result (between B and C on the Y-axis). In an ancient context there are therefore limits to the growth of the artisanal sector and these are determined by the need for subsistence goods production of the urban and rural

28 Poblome et al., in press. 


\section{Jeroen Poblome}

communities of Roman Imperial Sagalassos. So, even though there was a margin of growth in pottery production, comparing the impact of the local Hellenistic production of tablewares with its Roman Imperial counterpart, there was a 'pottery ceiling' that could not be breached. As a result, even if the producers would have wanted to, SRSW could simply never have played in the league of Eastern Sigillata A or other regional conglomerates of artisanal production, linked to towns and regions with a more extensive possible production output curve. The only way to exceed the margin of growth vis à vis the production of subsistence goods is by increasing the production efficiency of the potters. The fact that the fabric and slip of SRSW were made from one high quality clay raw material each, compared to multiple potential sources of the local Hellenistic tablewares, possibly reflects measures of increasing production efficiency ${ }^{29}$. The introduction of moulding techniques for the late Roman coroplast wares (oinophoroi, figurines, oil lamps) in the local Potters' Quarter is possibly another such example at attempted increased efficiency ${ }^{30}$.

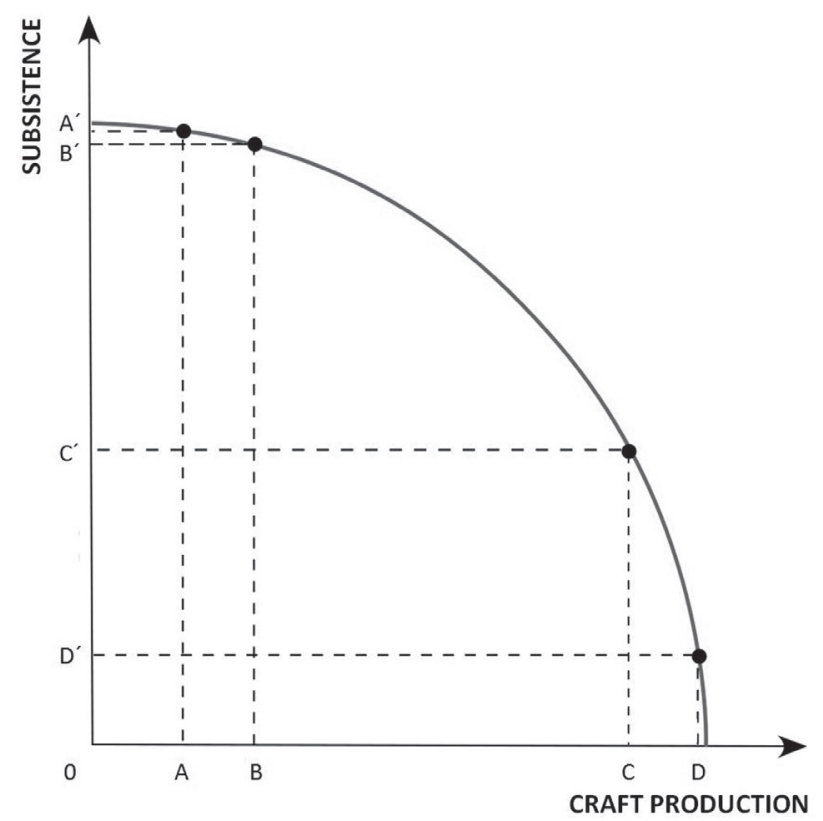

Fig. 2. Production Possibilities Curve applied to ancient Sagalassos

The fact that, to the best of my knowledge, no other Roman Imperial pottery production centre was active at the scale of the Potters' Quarter of Sagalassos in the wider region of SW Anatolia, and that the regional lines of pottery production that have been archaeologically attested ${ }^{31}$ possibly represent more limited opportunity costs less affecting the production of subsistence goods, makes Sagalassos and its Sagalassos red slip ware excep-

\footnotetext{
29 Poblome, in press.

30 Murphy and Poblome 2012.

31 On these, see Armstrong 2012.
} 
tional, at least within its own region. Considering that traditional productivity patterns in antiquity were mainly focused on subsistence goods, while always leaving a limited margin for some other type of productivity, implies that the community of Sagalassos made other choices and behaved somewhat differently in economic terms. As far as pottery production is concerned it is striking that, although local/regional production is no doubt more the norm throughout the Empire than even Roman ceramologists acknowledge today, only a few production centres (or regions of production if the actual place of manufacture is still unknown) made comparable choices to engage in comparably large-scale artisanal production, transgressing a certain level of opportunity costs. Even if only a few centres of production did this, it implies that Sagalassos was not a lone experiment in economics. Moreover, similar patterns seem to be in place for other types of craft production, such as textiles or glass ${ }^{32}$. I consider the replication of the pattern of production in other crafts to imply that both the local/regional level of craft production, as well as the somewhat higher scale of specialised artisanal output, such as attested with SRSW, should both be considered as structural features of the ancient economy and that the difference between these levels of production is related to choice in the face of opportunity costs.

In economic terms, I actually only see one way to explain the allowance of higher opportunity costs from specialisation in artisanal production affecting the output of subsistence goods: the functioning of the market economy in antiquity. The evidence on the value and price levels of pottery presented above sufficiently indicates that, in generic economic terms and apart from specific actions on behalf of central authorities, most transactions in Roman Imperial times took place between a supplier and a customer, on a voluntary basis. The actual transaction was confirmed by a price, with both parties guarding their interests. Prices were adjustable to circumstances, such as the late Roman patterns of inflation. By definition, these ground rules qualify the ancient economy as a free market economy. I repeat, however, that I do not advocate a naive understanding of the independent role of the Roman Imperial market. An instructive example that the market does not rule everything can actually also be provided by SRSW. Indeed, in the course of the second/early third century $\mathrm{AD}$, all other major producers of quality pottery tableware in the Roman East saw a considerable reduction of their output, if not an interruption of activities. In a naive understanding of the functioning of markets, this condition would have created a proverbial black hole in the (red) tableware market, providing a unique opportunity for the producers of SRSW to start trading their wares in every corner of the Roman eastern Mediterranean. This did not happen, however. Otherwise the pattern of distribution of SRSW would be much better documented for this period. In other words, either the stimuli of the market were not perceived by the producers of SRSW or they may have judged against expanding their production in the light of increasing opportunity costs.

In other words, it is of importance to consider which type of market economy is valid for Marc's Roman Imperial Sagalassos. Put simply, the specific nature of market economies is determined by the amount of suppliers and the amount of customers, the level of information these parties dispose of, the degree of product differentiation and the accessibility of the market. Table 2 presents a commonly used typology of markets,

32 Poblome 2004; Nenna 2000. 


\section{Jeroen Poblome}

based on the amount of suppliers versus the amount of customers. The more there are of each party the more competition can act in favour of all and the less one or other party can control the market and price settings. In the case of the Roman Imperial tableware market, which SRSW joined, it is fair to say that few communities engaged in largescale production and that they did this with many customers in mind. In other words, the market economy SRSW targeted can be defined as an oligopoly.

\begin{tabular}{|c|c|c|c|c|}
\hline \multicolumn{2}{|c|}{} & \multicolumn{3}{|c|}{ Customers } \\
\cline { 3 - 5 } \multicolumn{2}{|c|}{} & One & Few & Many \\
\hline \multirow{3}{*}{ Suppliers } & One & Bilateral monopoly & & Monopoly \\
\cline { 2 - 5 } & Few & & & Oligopoly \\
\cline { 2 - 5 } & Many & Monopsony & Oligopsony & Competition \\
\hline
\end{tabular}

Table 2. Typology of market economies.

Within an oligopoly, the customers are many, preventing them from influencing pricing or the market individually or as a group. The suppliers are few, however, making strategic market behaviour possible, with suppliers needing to take each other's strategic decisions into account. In this case, the policies and products of each supplier are influenced by those of the other suppliers in the same market. As the amount of suppliers is few, in some cases even mutual agreements become optional. Also the level and quality of information available to economic agents is important to consider in this context: the absence of global competition following from too limited information available to suppliers and customers implies that the ancient economy did not equal the capitalist market economy ${ }^{33}$. In this respect, the degree of competitiveness of oligopolitical markets can be situated between so-called perfect global competitive markets and monopolies. By definition, the ancient oligopolitical market strove towards stable conditions, which I should like to describe as a zero-risk economy with guaranteed sales for the few suppliers in the immediate, known environment and satisfied customers with a product of a constant quality level.

The distribution patterns of the protagonist types of tableware in the Roman Imperial eastern Mediterranean make sufficiently clear that all of these wares targeted first and foremost their regional markets. I suspect that in most cases the quantities consumed in the home market were sufficient for the artisanal enterprise to be successful. Further validation is required to test this hypothesis, but I find it an attractive thought to consider the home market as the most important one for oligopolitical artisanal producers and shift away from our modern archaeological appreciation of the importance of wares based on their distribution patterns. We should not throw away the latter, but such exercises should be better based on comparing production output balances and incorporating the widely understudied regional wares.

33 Bang 2008. 
The customers also seemed to have fared well under oligopolitical circumstances. When operational in stable conditions, such markets guaranteed good quality products that would evolve in style in correspondence between the few suppliers. In another, more socio-culturally oriented paper, I have proposed the concept of koinè to explain how and why Roman tableware reflects an interesting tension between stylistic similarities and differences, and applied the concept to re-introduce the old flag of Late Roman D wares incorporating SRSW, Cypriot Red Slip Ware as well as other SW Anatolian lines of tableware production ${ }^{34}$. Strikingly, more or less the same geographical zone of tableware koinè seems to have already been morphologically inspirational for the mid to late Hellenistic tablewares of Sagalassos ${ }^{35}$. As a result, it seems to me that defining the Roman Imperial tableware market as an oligopoly, provides the reverse, economic side to the originally socio-culturally defined coin/koinè, providing important keys to start understanding in detail why, how and when material culture production was set up, why, how and when the resulting morphologies can be intriguingly similar or not, and in which ways these processes created socio-cultural as well as economic opportunities for past communities, such as the one of Roman Imperial Sagalassos. Yes, somewhere in all of that, grand processes such as Hellenisation, Romanisation or Christianisation could have played a role, but the advantage of approaching economies such as the one of Roman Imperial Sagalassos from an oligopolitical angle and coupling these insights with looking for seemingly compatible socio-cultural matrices or koinè for the morphological inspiration of locally produced material culture, is that the full weight of local communities can be brought to bear, in all of its particularities and nuances.

Particularly the capacity to create the archaeological balance between contributing to the generic, oftentimes methodological debate and approaching the detailed behaviour of one specific past community, is what makes Marc's Sagalassos project so exciting and valuable to the wider scientific community. This paper hopes to have offered a snapshot of that potential. Secondly, the result is perhaps best described as an example of 'soft interdisciplinarity' situated within the humanities. But then again, as Marc demonstrated over and over again in exemplary ways, there should be no boundaries or presumptions when approaching the archaeology of Sagalassos or the interdisciplinary embeddedness of our archaeological discipline. I am very grateful to have been one of the scholars to have been affected by this unique interdisciplinary vision and I sincerely hope to have understood a little something of the potential of Marc's important project and legacy.

\section{Acknowledgements}

The research for this paper was supported by the CORES network of the Belgian Programme on Interuniversity Poles of Attraction (http://iap-cores.be/), the Research Fund of the University of Leuven (GOA 13/04), Project G.0562.11 of the Research Foundation Flanders (FWO), and the Hercules Foundation (AKUL/09/16). J. Poblome was appointed Francqui Research Professor for 2011-2014.

\footnotetext{
34 Poblome and Firat 2011.

35 Van der Enden et al., in press.
} 


\section{Jeroen Poblome}

\section{References}

Andreau 1974 = J. Andreau, Les affaires de Monsieur Jucundus, (Collection de l'École Française de Rome 19), Rome, 1974.

Armstrong 2012 = P. Armstrong, The survey pottery: Hellenistic and later, in J.J. Coulton, ed., The Balboura Survey and Settlement in Highland Southwest Anatolia, 2. The Balboura survey: detailed studies and catalogues, (British Institute at Ankara Monograph 43), London, 2012, pp. 31-82.

Bang 2008 = P.F. Bang, The Roman Bazaar. A Comparative Study of Trade and Markets in a Tributary Empire, Cambridge, 2008.

Berlage and Decoster 2005 = L. Berlage and A. Decoster, eds., Inleiding tot de economie, Leuven, 2005.

Drexhage et al. 2002 = H.-J. Drexhage, H. Konen and K. Ruffing, Die Wirtschaft des Römischen Reiches (1.-3. Jahrhundert). Eine Einführung, Berlin, 2002.

Hansen 2006 = M.H. Hansen, The Shotgun Method: the Demography of the Ancient Greek City-state Culture, Missouri, 2006.

Jongman 2007 = W.M. Jongman, The Early Roman Empire: Consumption, in W. Scheidel, I. Morris and R.P. Saller, eds., The Cambridge Economic History of the Greco-Roman World, Cambridge, 2007, pp. 592-618.

Lo Cascio 2007 = E. Lo Cascio, The Early Roman Empire: the state and the economy, in W. Scheidel, I. Morris and R.P. Saller, eds., The Cambridge Economic History of the Greco-Roman World, Cambridge, 2007, pp. 619-647.

Lund 2005 = J. Lund, An economy of consumption: the Eastern Sigillata A industry in the late Hellenistic period, in Z.H. Archibald, J.K. Davies and V. Gabrielsen, eds., Making, Moving and Managing. The New World of Ancient Economies, 323-31 B.C., Oxford, 2005, pp. 233-254.

Matthews 2006 = J. Matthews, The Journey of Theophanes. Travel, Business and Daily Life in the Roman East, Yale, 2006.

Mitchell and Waelkens 1988 = S. Mitchell and M. Waelkens, Cremna and Sagalassus 1987, "Anatolian Studies", 38, 2008, pp. 53-64. http://dx.doi.org/10.2307/3642841.

Nenna 2000 = M.-D. Nenna (ed.), La route du verre. Ateliers primaires et secondaires du second millénaire av. J.-C. au Moyen Âge, (Travaux de la Maison de l'Orient Méditerranéen 33), Lyon, 2000.

Peña 2007 = J.T. Peña, Roman Pottery in the Archaeological Record, Cambridge, 2007.

Murphy and Poblome 2012 = E. Murphy and J. Poblome, Technical and Social Considerations of Tools from Roman-period Ceramic Workshops at Sagalassos (Southwest Turkey): Not Just Tools of the Trade?, “Journal of Mediterranean Archaeology", 25, pp. 69-89. http://dx.doi.org/10.1558/jma.v25i2.197.

Persson 2010 = K.G. Persson, An Economic History of Europe. Knowledge, Institutions and Growth, 600 to the present, Cambridge, 2010.

Poblome 1999 = J. Poblome, Sagalassos Red Slip Ware. Typology and Chronology, (Studies in Eastern Mediterranean Archaeology 2), Turnhout, 1999.

Poblome 2004 = J. Poblome, Comparing Ordinary Craft Production: Textile and Pottery Production in Roman Asia Minor, "Journal of Economic and Social History of the Orient", 47, 2012, pp. 491-506. http://dx.doi.org/10.1163/1568520042467163.

Poblome et al. 2007 = J. Poblome, D. Malfitana and J. Lund, Tempus fugit. "FACTA" manent. Editorial statement, "FACTA. A Journal of Roman Material Culture Studies", 1, 2007, pp. 13-20. 
Poblome et al. 2010 = J. Poblome, P. Bes, B. De Cupere, V. Lauwers, K. Romanus, A.K. Vionis and

M. Waelkens, Sic transit gloria mundi. Does it really? Wasting seventh century AD Sagalassos (SW Turkey), in S. Menchelli, S. Santoro, M. Pasquinuci and G. Guiducci, eds., LRCW3. Late Roman Coarse Wares, Cooking Wares and Amphorae in the Mediterranean. Archaeology and Archaeometry. Comparison between Western and Eastern Mediterranean, (British Archaeological Reports International Series 2185), Oxford, 2010, pp. 791-801. Poblome and Firat 2011 = J. Poblome and N. Firat, Late Roman D. A matter of open(ing) or closed horizons?, in M.A. Cau, P. Reynolds and M. Bonifay, eds., LRFW1. Late Roman Fine Wares. Solving Problems of Typology and Chronology. A review of the Evidence, Debate and New Contexts, (Roman and Late Antique Mediterranean Pottery 1), Oxford, 2011, pp. 49-55.

Poblome et al. 2012a = J. Poblome, P. Bes and R. Willet, Thoughts on the Archaeological residue of Networks. A View from the East, in S. Keay, ed., Rome, Portus and the Mediterranean, (Archaeological Monographs of the British School at Rome 21), London, 2012, pp. 393-401.

Poblome et al. 2012b = J. Poblome, D. Malfitana and J. Lund, Scherben bringen Glück. HEROM's editorial statement, "HEROM. Journal on Hellenistic and Roman Material Culture", 1, 2012, pp. 7-22.

Poblome, in press = J. Poblome, The potters of Sagalassos revisited, in M. Flohr and A. Wilson, eds., Beyond Marginality. Craftsmen, Traders and the Socioeconomic History of Urban Communities in the Roman World, Oxford, in press.

Poblome et al., in press = J. Poblome, D. Braekmans, B. Mušič, M. Van der Enden, B. Neyt, B. De Graeve and P. Degryse, A pottery kiln underneath the Odeon of ancient Sagalassos, SW Turkey. The excavation results, the table wares and their archaeometrical analysis, in N. Fenn and C. Römer-Strehl, eds., Networks in the Hellenistic world According to the Pottery in the Eastern Mediterranean and Beyond, (British Archaeological Reports International Series), Oxford, in press.

Scheidel 2007 = W. Scheidel, Demography, in W. Scheidel, I. Morris and R. Saller, eds., The Cambridge Economic History of the Greco-Roman world, Cambridge, 2007, pp. 38-86.

Temin 2013 = P. Temin, The Roman Market Economy, Princeton, 2013.

Van der Enden et al., in press = M. Van der Enden, J. Poblome and P. Bes, From Hellenistic to Roman Imperial in Pisidian Tableware: The Genesis of Sagalassos Red Slip Ware, in Third International Pottery Workshop at Nieborów, in press.

van Nijf 1997 = O.M. van Nijf, The Civic World of Professional Associations in the Roman East, (Dutch Monographs on Ancient History and Archaeology 17), Amsterdam, 1997.

Wieling 2000 = H. Wieling, Vertragsgestaltung der römischen Keramikproduktion, in K. Strobel, ed., Forschungen zur römischen Keramikindustrie. Produktions-, Rechts- und Distributionsstrukturen, (Trierer Historische Forschungen 42), Mainz, 2000, pp. 9-22.

Willet and Poblome $2011=\mathrm{R}$. Willet and J. Poblome, The Pale Red Slipped Dot, "FACTA. A Journal of Roman Material Culture Studies", 5, 2011, pp. 101-110.

Zimmermann 2002 = C. Zimmermann, Handwerkvereine im griechischen Osten des Imperium Romanum, (Römisch-Germanisches Zentralmuseum. Forschungsinstitut für Vor- und Frühgeschichte Monographien 57), Mainz, 2002. 